\title{
Baptismal "Spirituality" in the Early Church and Its Implications for the Church Today
}

\author{
Maxwell E. Johnson
}

Let me begin with two quotes from a recent collection of essays by British Methodist liturgical theologian Geoffrey Wainwright, both of which, I believe, speak to the overall theme of this year's liturgical institute. First, in an essay originally published in 1988, Wainwright says: "Without the heartbeat of the sacraments at its center, a church will lack confidence about the gospel message and about its own ability to proclaim that message in evangelism, to live it out in its own internal fellowship, and to embody it in service to the needy." And, second, in an essay appearing originally in 1993, he writes that "a deeper replunging into its own tradition will, in my judgment, be necessary if the church is to survive in recognizable form, particularly in our western culture." The "heartbeat of the sacraments" at the very center of the church's life and the need for "a deeper replunging into its own tradition," provide the overall focus for my task this morning; that is, looking at the notion of baptismal spirituality in the early Christian churches and its usefulness or implications for the life of the church today. In doing so, I wish to divide my comments into three sections: 1) Not early Christian baptismal spirituality but spiritualities; 2) the so-called "Golden Age" of the baptismal process; and 3 ) the implications or usefulness of this spirituality for the church today.

\section{Not Early Christian Baptismal Spirituality but Spiritualities}

It is often said that if early Christianity had used the later Roman Catholic terminology of "blessed sacrament" to refer to any of its sacramental rites, it would have used it to refer to baptism and not to the Eucharist (a term, by the way, actually used by Luther as early as 1519 to

'Geoffrey Wainwright, Worship with One Accord: Where Liturgy \& Ecumenism Embrace (New York: Oxford University Press, 1997), 106.

${ }^{2}$ Ibid., 138. 
talk about baptism ${ }^{3}$ ). But, of course, what would have been meant by baptism in this early context was not simply the water bath and trinitarian formula, the later Scholastic precision of "matter" and "form" or the Reformation language of "water" and the "Word," but would have included the entire catechetical and sacramental-ritual process by which Christians, in the words of Tertullian, were "made, not born," that foundational and formative experience of church leading, at least in the case of adult converts, from initial conversion and inquiry all the way to full incorporation within the life of the church. That is, this "blessed sacrament" of baptism in early Christianity encompassed what the recent Lutheran World Federation Chicago Statement on Worship and Culture: Baptism and Rites of Life Passage describes as:

a) formation in the one faith (traditionally known as the catechumenate), b) the water-bath, and c) the incorporation of the baptized into the whole Christian community and its mission. This latter incorporation is expressed by the newly baptized being led to the table of the Lord's Supper, the very table where their baptismal identity will also be strengthened and re-affirmed throughout their life. ${ }^{4}$

Such an all-encompassing view of baptism and the need for solid formation in the Christian faith brought with it several implications for the day-to-day organization of the church itself.

While our evidence is not what we wish it would be for the first three centuries of the Christian era, there is no question but that the way of forming new Christians through this ritual process was the task of the whole church itself, all the way from the "agapaic" life of the community, especially those whose lives witnessed directly to the gospel in the presence of others, to the various ministries needed throughout the catechumenate and within the celebration of the rites themselves. An early church order, the so-called Apostolic Tradition, ascribed to Hippolytus of Rome in the early third century (ca. 215), but which is probably neither "apostolic," nor of "Hippolytan" authorship, nor "Roman," nor early third century,"

${ }^{3}$ See "The Holy and Blessed Sacrament of Baptism" (1519), in Luther's Works, vol. 35, ed. Jaroslav Pelikan and Helmut T. Lehmann (Philadelphia: Fortress Press, 1960), 23-44.

${ }^{4}$ Chicago Statement on Worship and Culture: Baptism and Rites of Life Passage (Geneva: Lutheran World Federation, 1998), par. 2.1.

${ }^{5}$ For recent studies see Wolfram Kinzig, Christoph Markschies, and Markus Vinzent, Tauffragen und Bekenntnis: Studien zur sogennanten 'Traditio Apostolica' zu den 'Interrogationes de fide' und zum 'Römischen Glaubensbekenntnis' (Berlin: 
testifies to this variety of people involved in the process, with special roles assigned to sponsors who present and testify to the worthiness of the baptismal candidates, to lay and ordained catechists, to deacons, presbyters, and the bishop, who, as the chief pastor had the responsibility of overseeing the entire process and concluded the baptismal rite itself with a hand-laying gesture of pneumatic blessing and paternity, a kiss, and welcome into the eucharistic communion of the church. ${ }^{6}$ Other documents, such as the late first- or early second-century Didache, or Teaching of the Twelve Apostles, underscore the involvement of the whole community in the prebaptismal fast that would have been undertaken by those preparing for baptism. ${ }^{7}$ Indeed, the royal priesthood of the faithful signified throughout the baptismal process and into which the neophytes were incorporated was regularly exercised in the eucharistic assembly, as we know already from Justin the Martyr in the mid-second century ${ }^{8}$ and from the mid-third century Syrian church order, the Didascalia Apostolorum with various roles for lectors, door keepers, even widows and, possibly, women presbyters, cantors, deacons - both male and female-presbyters, and bishops, with the faithful themselves presenting the "gifts" for the meal and for the poor and offering prayers of intercession for the church and the world. ${ }^{9}$ In many ways, the liturgical assembly itself was but the gathering of the church to exercise its common baptismal priesthood before God, in

Walter de Gruyter, 1999); M. Metzger, "Nouvelles perspectives pour la prétendue Tradition apostolique," Ecclesia Orans 5 (1988), 241-259; M. Metzger, "Enquêtes autour de la prétendue Tradition apostolique," Ecclesia Orans 9 (1992), 7-36; M. Metzger, "A propos des règlements écclesiastiques et de la prétendue Tradition apostolique," Revue des sciences religieuses 66 (1992), 249-261; and Paul Bradshaw, "Re-dating the Apostolic Tradition: Some Preliminary Steps," in Rule of Prayer, Rule of Faith: Essays in Honor of Aidan Kavanagh, OSB, ed. John Baldovin and Nathan Mitchell (Collegeville, MN: Liturgical Press, 1996), 3-17.

${ }^{6}$ Goeffrey J. Cuming Hippolytus: A Text for Students, Grove Liturgical Study 8 (Bramcote/Nottingham: Grove Books, Ltd., 1976), 17.

${ }^{7}$ For a text of the Didache, see Cyril Richardson, Early Christian Fathers (New York: Macmillan, 1970), 171-179.

${ }^{8}$ Justin Martyr, First Apology 61. For the Greek text, see Patrologia graeca, ed. J.-P. Migne, vol. 6 (Paris, 1857), $420 \mathrm{ff}$.

'Sabastian Brock and Michael Vasey, The Liturgical Portions of the Didascalia, Grove Liturgical Study 29 (Bramcote/Nottingham: Grove Books, Ltd., 1982). 
union with the one high priest of the church, Jesus Christ, in the power of his Holy Spirit.

Because of baptism, that is, the life-shaping direction of the whole. baptismal process, it is no wonder that early Christians, especially people like Tertullian and Cyprian in the North African West, Gregory Thaumaturgos (the Wonder-Worker) in the Syrian East, and Origen of Alexandria in Egypt, struggled with the question of how to treat serious postbaptismal sin (e.g., what is sometimes referred to as the traditional triad of apostasy, adultery, and murder). And it is no wonder that after such "shipwreck" on the rock of postbaptismal sin that the answer given to this problem was nothing other than a "return to baptism" itself through the process of public and "canonical penance," a process which mirrored the rigors of the catechumenate itself, and a process understood, in the words of Tertullian, to be a "plank" thrown to the drowning sinner as one more chance, but only one more chance, to get it right. ${ }^{10}$ If the Eucharist was both the culmination and the ongoing repeatable sacrament of baptismal initiation, then canonical penance was the way of return for the excommunicated, those cut off from eucharistic communion, to the regular sacramental life of the church. Together with catechumens and the "elect," that is, those in the final stages of baptismal preparation, these penitents would be regularly dismissed with prayer and hand-laying from the Sunday assembly after the liturgy of the Word, and, after a designated time of penance (usually determined according to the gravity of their sin), would be reconciled with Christ and the church through the hand-laying absolution of the bishop, an event which, in the later Roman tradition would take place with great solemnity on Holy ("Maundy") Thursday. Eucharist, penitence, and, indeed, all of ecclesial life in early Christianity seems to have flowed from the all-encompassing catechetical and sacramental-ritual process of baptism, just as later evidence for early Christian proclamation of the Word stems, in large part, from extant preand postbaptismal catechetical homilies.

Unfortunately, we are not completely certain about the overall contents of specific catechetical instruction provided to catechumens within the churches of the first three centuries. From scattered references throughout early Christian writings, however, it is quite clear that some kind of explanation of the scriptures in relationship to salvation in Christ along with continual ethical or moral formation in the life of the Christian

${ }^{10}$ Tertullian, De poenitentia 7. On the process of "canonical penance" in early Christianity, see James Dallen, The Reconciling Community: The Rite of Penance (Collegeville, MN: Liturgical Press, 1986). 
community were essential components of this process. The first six chapters of the Didache, for example, describe what is called "The Two Ways," that of life and death. " Significantly, the contents of these first six chapters are not concerned with Christian doctrine but focus, instead, on the Ten Commandments and the type of ethical-moral life expected from those who are to be members of Christ through baptism. Similarly, chapter 20 of the so-called Apostolic Tradition refers to an examination of those who have completed the catechumenate and now desire to enter the next stage of the process, "election," leading more immediately to baptism. Again, the questions they are asked at this point are not questions about doctrine but about the quality of their lives. Chapter 20 directs:

And when those who are to receive baptism are chosen, let their life be examined: have they lived good lives when they were catechumens? Have they honoured the widows? Have they visited the sick? Have they done every kind of good work? And when those who brought them bear witness to each: 'He has,' let them hear the gospel. ${ }^{12}$

We Lutherans tend to become a bit uncomfortable with a process that places so much emphasis upon the moral life and, apparently, so little on doctrine. How, we might ask, can persons seek to become Christian if they haven't heard or don't hear the gospel (cf. Rom 10:17)? Yet, as recent studies are beginning to show, ${ }^{13}$ it is quite possible that in early Christianity, catechumens themselves, as the above text from Apostolic Tradition 20 seems to imply, did not "hear," and, hence, were not even introduced to, the "gospel" or Gospels until they were elected to the final stage of baptismal preparation. Formation thus had more to do with an apprenticeship in learning to live as Christians. And, if we are to believe the standard textbook theory that the regular catechumenate in the pre-Nicene church could last as long as three years in duration, this is a rather long time for "converts" not to be introduced to the very central texts of the Christian tradition. Yet, some remnant of this process may, in fact, be contained in the seventh- or eighth-century Gelasian Sacramentary, where, during the third week of Lent, the "elect," now by this time clearly infants brought by their parents to public catechesis,

\footnotetext{
"See above, note 7.
}

${ }^{12}$ Cuming, Hippolytus: A Text for Students, 17.

${ }^{13}$ See Paul Bradshaw, "The Gospel and the Catechumenate in the Third Century," Journal of Theological Studies 50/1 (April 1999): 143-152. 
received the Gospels themselves by means of an extended introduction to each one by a deacon. ${ }^{14}$ While the doctrinal Lutheran in me bristles a bit at this, I wonder if Luther himself didn't intuit this kind of early Christian baptismal process in the very organization of his Small Catechism, where instruction in the meaning of the Ten Commandments comes first, before everything else and so precedes that of the Apostles' Creed, the Lord's Prayer, and the sacraments.

Nevertheless, if baptism in early Christianity shaped the whole of Christian life and identity and fostered a "spirituality" or way of life in the Holy Spirit which was ecclesial, ethical, social, and sacramental, the baptismal liturgy, including its eucharistic culmination, as the church's great "School of Prayer," also shaped the teaching or doctrine of the church itself. Although true prayer is always a gift of the Holy Spirit (Rom 8:26-27 and Gal 4:6-7) and cannot adequately be "taught," the great gift of the church's liturgical tradition is that it provides both a language and structure for prayer. In other words, as early Christianity knew even without written liturgical texts, the way to learn and teach Christian prayer is to learn from the liturgy itself how it is that the church actually prays in its assemblies. Within early Christianity much of this happened simply as the result of the catechumens' ongoing participation in the liturgical life of the church through the daily public gatherings for what came to be called the divine office or liturgy of the hours and through the Sunday eucharistic liturgy. And it is the very structure and contents of this prayer of the church that provided a model for all of Christian prayer, namely, that Christian prayer is "trinitarian" in structure and focus. That is, Christian prayer is addressed to God, "our Abba, Father;" through Jesus Christ the Son, our great high priest and mediator; in the Holy Spirit, the Comforter, the Paraclete, the Counselor, who leads us by Word and sacrament to confess that Jesus is Lord (1 Cor 12:3). Note, for example, the concluding formula for the Prayer of the Day still in our own worship books: “... through your Son Jesus Christ our Lord who lives and reigns with you and the Holy Spirit, one God, both now and forever." Or, note the concluding doxology at the end of the Great Thanksgiving: "Through him, with him, in him, in the unity of the Holy Spirit, all honor and glory is yours, almighty Father, now and forever. Amen"

\footnotetext{
${ }^{14}$ See E.C. Whitaker, Documents of the Baptismal Liturgy, $2^{\text {nd }}$ ed. (London: SPCK, 1970), 172ff. [Editor's note: Since this address was given in 1999, a new edition of Whitaker's volume has been published. This $3^{\text {rd }}$ edition, revised and expanded by Maxwell E. Johnson, was published by Liturgical Press, 2003.]
} 
Furthermore, an ancient Christian principle, often summarized by the Latin phrase, lex orandi ... lex credendi, states that the "rule of praying establishes the rule of believing." That is, the "faith" of the church is both constituted and expressed by the "prayer" of the church. Indeed, the liturgy is not only the "school for prayer" but also the "school for faith" and as such, serves as a continual formative-fitting "text" for all the baptized themselves in their lifelong process of continual formation in the faith. Long before there was an Apostles' or Nicene Creed, or an explicit "doctrine" of the Trinity, it was through the prayer of blessing or thanksgiving over the baptismal waters, through the candidate's threefold confession of faith in the Father, Son, and Holy Spirit in the context of baptism itself ("Do you believe in ...?" "I believe ..."), and through the great eucharistia over the bread and cup of the Lord's Supper, consisting of praise to God for the work of creation and redemption, thanksgiving for the life, death, resurrection, and ascension of Christ, and invocation of the Holy Spirit, that the church professed its faith in the Trinity by means of doxology and praise. In other words, it was the liturgy-baptismal and eucharistic-which assisted in forming orthodox Christian teaching. That is, orthodox trinitarian and christological doctrine developed, in large part from the church at prayer, as the baptismal-credal profession of faith gave rise to the "official" creeds themselves, as prayer to Christ contributed to understanding his homoousios with the Father, as the Holy Spirit's divine role in baptism shaped the theology of the Spirit's divinity in Athanasius, the Cappadocian Fathers, and the Council of Constantinople, and even as early devotion to Mary as Theotokos gave rise, in part, to the decree of the Council of Ephesus. While orthodoxy means "right thinking" or "right opinion," such "right thinking" developed, at least in part, from the doxology of the church, where several of our central Christian doctrines were prayed liturgically long before they were formalized dogmatically.

Indeed, trinitarian faith was born in the font and nurtured and sustained at the table, good enough reason, in my opinion, to be very cautious today of those who would replace the liturgy with something else in the name of contemporary "relevance" or "hospitality to seekers" or of those who so tinker with classic liturgical formulas that one is left wondering if it is the Triune God of scripture and the classic tradition who is intended any longer. ${ }^{15}$ Careless tinkering with the church's lex orandi can have drastic consequences for the church's lex credendi.

\footnotetext{
${ }^{15}$ See Wainwright, Worship with One Accord, 120, 122.
} 
Everything I have said up to this point is largely prologomena to the first point I want to make in this address, namely, that there is no one baptismal spirituality in early Christianity but several complementary baptismal spiritualities. In the New Testament itself we are presented with a rich mosaic of baptismal images: forgiveness of sins and the gift of the Holy Spirit (Acts 2:38); new birth through water and the Holy Spirit (John $3: 5$; Titus 3:5-7); putting off of the "old nature" and "putting on the new," that is, "being clothed in the righteousness of Christ" (Gal 3:27; Col 3:910); initiation into the "one body" of the Christian community (1 Cor 12:13; see also Acts 2:42); washing, sanctification, and justification in Christ and the Holy Spirit (1 Cor 6:11); enlightenment (Heb 6:4, 10:32; 1 Peter 2:9); being "anointed" and/or "sealed" by the Holy Spirit (2 Cor $1: 21-22 ; 1$ John 2:20, 27); being "sealed" or "marked" as belonging to God and God's people (2 Cor 1:21-22; Eph 1:13-14, 4:30; Rev 7:3); and, of course, being joined to Christ through participation in his death, burial, and resurrection (Rom 6:3-11; Col 2:12-15). From this mosaic, two will stand out with particular emphasis in early Christianity: baptism as new birth through water and the Holy Spirit (John 3:5ff.); and baptism as being united with Christ in his death, burial, and resurrection (Rom 6:3-11).

And, as Christianity developed and spread throughout the diverse cultures of the ancient world, the "one baptism" (Eph 4:5) of the church was expressed by means of a variety of different liturgical practices and interpretations within the distinct Christian churches. For the early Syriac-speaking Christians of East Syria, living in what is modern-day Iraq and Iran, it seems the catechumenate itself was quite minimal, and the rites themselves may have taken place on Epiphany, the great Theophany of Christ in the Jordan, his own baptismal "birth" in the Jordan. A "new birth" rite understood as the means by which the Holy Spirit, through a prebaptismal anointing, assimilated the neophyte to the messianic priesthood and kingship of Christ. ${ }^{16}$ For the early Greek- and Coptic-speaking Egyptian Christian tradition, known by Clement and Origen of Alexandria, a forty-day prebaptismal catechumenate commencing on Epiphany, again understood as the feast of Jesus' Baptism, seems to have led to baptism on the sixth day of the sixth week of this

\footnotetext{
${ }^{16}$ On this tradition see especially the work of Gabriele Winkler, "The Original Meaning of the Prebaptismal Anointing and its Implications," in Living Water, Sealing Spirit: Readings on Christian Initiation, ed. Maxwell E. Johnson (Collegeville, MN: Liturgical Press, 1995), 58-81; and the recent study of Killian McDonnell, The Baptism of Jesus in the Jordan: The Trinitarian and Cosmic Order of Salvation (Collegeville, MN: Liturgical Press, 1996).
} 
post-Epiphany fast (sometime in mid-February). ${ }^{17}$ The rite itself, again focusing possibly on a pre-baptismal anointing, appears to have been understood not in terms of death and resurrection imagery but rather as "crossing the Jordan" with our Joshua-Jesus. For Origen himself the imagery of catechumenate and baptism had little to do with the paschal language of crossing the Red Sea or death and burial in Christ. Rather, for him, the Exodus from Egypt signified entrance into the forty-year catechumenate, and it was the Israelites' crossing of the Jordan that functioned as the great Old Testament baptismal typology. ${ }^{18}$ In fact, within the first three centuries of the church's existence, it was only among the Latin-speaking Christians of the North African churches and the undoubtedly multiethnic groups that made up the Christian communities living in Rome where we begin to encounter both the possibility of baptism at Easter and the concomitant use of Romans 6 theology to interpret such a practice. But even here we should be cautious. Our major evidence for this is Tertullian, who writes:

The Passover [i.e., Easter] provides the day of most solemnity for baptism, for then was accomplished our Lord's passion, and into it we are baptized.... After that, Pentecost is a most auspicious period for arranging baptisms, for during it our Lord's resurrection was several times made known among the disciples, and the grace of the Holy Spirit first given.... For all that, every day is a Lord's day: any hour, any season, is suitable for baptism. If there is any difference of solemnity, it makes no difference to the grace. ${ }^{19}$

It is thus not known if Easter baptism was but a theological preference for Tertullian himself, which he wished to advocate, or a practice that he actually knew. In fact, our only clear reference to Easter baptism in the first few centuries is Hippolytus of Rome's Commentary on Daniel, in which he refers to the "bath" being open at Pascha, but it is not clear if at

${ }^{17}$ On this see Thomas Talley, The Origins of the Liturgical Year, $2^{\text {nd }}$ ed., (Collegeville, MN: Liturgical Press, 1986), $163 \mathrm{ff}$.

${ }^{18}$ On Origen's baptismal theology see J. Laporte, "Models from Philo in Origen's Teaching on Original Sin," in Living Water, Sealing Spirit, 101-117; C. Blanc, "Le Baptême d'après Origène," Studia Patristica 11 (1972):113-124; H. Crouzel, "Origène et la structure du sacrement," in Bulletin de littérature ecclesiastique 2 (1962), 81-92; Jean Daniélou, Bible and Liturgy (Notre Dame, IN: University of Notre Dame Press, 1956), 99-113; and Jean Daniélou, Origen, trans. Walter Mitchell (New York: Sheed and Ward, 1955), 52-61. 10.]

${ }^{19}$ Documents of the Baptismal Liturgy, 9, emphasis added. [Editor's note: $3^{\text {rd }}$ ed., 
Rome this was the only occasion or not. ${ }^{20}$ For that matter, if Hippolytus himself had anything to do with the so-called Apostolic Tradition, it is interesting to note that nowhere in that document is Easter ever referred to as the occasion for baptism. While the description of baptism taking place at the end of an all-night Saturday vigil is certainly consistent with Easter baptism, the document does not say that it was Easter and, for that matter, all-night vigils were more common in Christian antiquity than in the later tradition.

Similarly, apart from the possibility of a forty-day prebaptismal catechumenate in early Egypt, we simply do not know the length or duration of the final preparation period elsewhere or when during the year it may have taken place. While Apostolic Tradition 17 refers to the possibility of a total of three years' preparation, other sources suggest a total of three months, and contemporary scholarship has argued that a pattern of three weeks of final preparation may have been customary in several places. ${ }^{21}$

My point in all this is that today, in spite of the several common elements we might note regarding the baptismal process in the early church, we must be very cautious about assuming a single, universal, normative, and fixed pattern or interpretation of baptism in early Christianity. Above all, we need to avoid the standard cliche that "the early church baptized at Easter" and knew a process consisting of, for example, a primitive period of catechesis corresponding to what would later become Lent with baptism at Easter, interpreted according to Paul's theology of death and burial in Christ expressed in Romans 6. What we do know about early Christian baptismal practices and interpretation disagrees with that assumption. While a Romans 6 theology of baptism is important and certainly cherished by us Lutherans for good theological reasons, we Lutherans simply have to get used to the fact that Paul's baptismal theology was relatively silent in the first few centuries of the church and was only rediscovered in the mid- to late-fourth century.

This silence of Paul in the early centuries should speak volumes about notions of early Christian baptismal spirituality. For, from the early Syrian-and possibly Egyptian-traditions comes a whole cluster of baptismal images that have little to do with passing from death to life, or

\footnotetext{
${ }^{20}$ Maurice Lefévre, ed., Commentaire sur Daniel, intro. Gustave Bardy, Sources̀ chrétiennes 14 (Paris, 1947), 100.

${ }^{21}$ See Maxwell E. Johnson, "From Three Weeks to Forty Days: Baptismal Preparation and the Origins of Lent," in Living Water, Sealing Spirit, 118-136.
} 
with sharing in the dying and rising of Christ through baptism. Such images, noted the late Mark Searle, include seeing the font as womb, rather than tomb, literally called the "Jordan" itself in some traditions, images like "adoption, divinization, sanctification, gift of the Spirit, indwelling, glory, power, wisdom, rebirth, restoration, [and] mission." 22 Hence, a spirituality based on baptism as death, burial, and resurrection is one powerful way of articulating a way of Christian identity, life, and service. A spirituality based on the new birth theology of John 3, or on images of baptismal adoption, is yet another. For one spirituality, Christ's own death and resurrection is of paramount importance. For the other spirituality, the Incarnation itself is viewed as salvific, as, for example, in the words of Athanasius, "God became what we are so that we could be made what he is," ${ }^{23}$ that is, through baptism we become by adoption what Christ is by nature. For one spirituality, baptism is the tomb in which the sinful self is put to death in Christ. For the other spirituality, baptism is the womb through which the mothering spirit of God-Spirit is feminine and actually called "Mother" in the early Syriac tradition-gives new birth and new life. For one spirituality, Adam is to be put to death. For the other spirituality, Adam is to be sought after and rescued from sin, death, and bondage. For one spirituality, Easter is the feast par excellence, the very center of the liturgical year. For the other spirituality, it is the Theophany of Christ in the Jordan at Epiphany, the very manifestation of the Trinity in the waters of the font, that assumes great importance. Indeed, how one thinks of baptism will shape how one views Christian life and identity. Even if these two views are not contradictory or exclusive, they did and do shape distinct emphases and orientations to which we should pay attention still today.

\section{The So-Called "Golden Age" of the Baptismal Process}

We liturgists are often accused of trying to make the contemporary church fit a presumed normative liturgical pattern as it is reconstructed from the various extant sources of the fourth and fifth centuries, that period Johannes Quasten called "the Golden Age of Greek Patristic

\footnotetext{
${ }^{22}$ Mark Searle, "Infant Baptism Reconsidered," in Living Water, Sealing Spirit, 385 .

${ }^{23}$ Athanasius, De Incarnatione Verbi Dei 54.
} 
Literature. ${ }^{24}$ I doubt that the Roman Catholic Rites of Christian Initiation of Adults (RCIA) or the recent Lutheran adaptation of the catechumenal process, Welcome to Christ, do much to persuade our critics that some kind of modern liturgical repristination of this "Golden Age" is not being intended today. Even the subtitle of Edward Yarnold's new edition of his The Awe-Inspiring Rites of Christian Initiation: The Origins of the R.C.I.A. would seem to provide, quite unintentionally, some fuel for such a critique. And, of course, it is true that our contemporary knowledge of the early Christian baptismal process is due, in large part, to the documentary evidence that exists from this period, namely, the extant catechectical homilies of the great "mystagogues" (e.g., Cyril of Jerusalem, John Chrysostom, and Theodore of Mopsuestia for the East, and Ambrose of Milan for the West).

At the same time, however, it ought not be forgotten that the various cultural and social shifts in the Constantinian era and beyond brought with them the need for the churches themselves to respond to those changing circumstances. One of those responses was the first of several great periods of liturgical reform and renewal in the history of the church. ${ }^{25}$ But, as recent liturgical scholarship has demonstrated, what we see in this first reform or renewal is the development of what has been called "liturgical homogeneity," wherein through a process of assimilation to the practices of the great patriarchal and pilgrimage churches of the world-e.g., Rome, Jerusalem, Alexandria, Antioch, and Constantinople - and through the cross-fertilization of borrowing and exchange, distinctive local practices and theologies disappear in favor of others becoming copied, adapted, and synthesized. ${ }^{26}$ Therefore, what we often appeal to as the early Christian pattern for baptism is but the end result of a process of assimilation, adaptation, and change, wherein some

\footnotetext{
${ }^{24}$ This is the subtitle of Quasten's third volume of his monumental work, Patrology (Utrecht, Netherlands: Spectrum, 1966).

${ }^{25}$ The other periods of liturgical reform and renewal in the history of the church are, of course, Charlemagne's wholesale adoption of the Roman rite as the normative rite for Western Europe in the ninth century, the sixteenth-century Protestant and Catholic Reformations and their liturgical products, and the period of ecumenical liturgical convergence following the Second Vatican Council and continuing still today among us.

${ }^{26}$ See Paul Bradshaw, "The Homogenization of Christian Liturgy - Ancient and Modern: Presidential Address," Studia Liturgica 26 (1996): 1-15.
} 
of the distinctive and rich theologies and spiritualities of an earlier period either disappear or are subordinated to others.

As a result of "mass conversions" in the wake of Constantine's own "conversion," 27 the subsequent legalization and eventual adoption of Christianity as the official religion of the Roman Empire, and the trinitarian and christological decisions of the first ecumenical councils, this fourth- and fifth-century "homogenization" in liturgical practice is easily demonstrated. Thanks to the extant catechectical homilies noted above, while some local diversity continued to exist, the following came to characterize the overall ritual pattern of baptism throughout the Christian East:

1. The adoption of paschal baptism and the now forty-day season of Lent as the time of prebaptismal (daily) catechesis on scripture, Christian life, and, especially, the Nicene Creed for the photizomenoi (those to be "enlightened");

2. The use of scrutinies (examinations) and daily exorcisms throughout the period of final baptismal preparation;

3. The development of specific rites called apotaxis (renunciation) and syntaxis (adherence) as demonstrating a "change of ownership" for the candidates;

4. The development of ceremonies like the solemn traditio and redditio symboli (the presentation and "giving back" of the Nicene Creed);

5. The reinterpretation of the once pneumatic prebaptismal anointing as a rite of exorcism, purification, and/or preparation for combat against Satan;

6. The rediscovery and use of Romans 6 as the dominant paradigm for interpreting the baptismal immersion or submersion as entrance into the "tomb" with Christ;

\footnotetext{
${ }^{27}$ How widespread such "mass conversion" actually was in this time period has been questioned recently by Rodney Stark, The Rise of Christianity: A Sociologist Reconsiders History (Princeton, NJ: Princeton University Press, 1996), who suggests that a major part of the increase in Christianity had to do, among other things, with the large number of women, fertility, and substantially higher birth rates among Christians in this period in contrast with their pagan neighbors. Similarly, according to Stark, Christianity's appeal to women, its high view of marriage for both partners, its prohibition of abortion and infanticide, especially of female babies, and its offer of status and protection to women, and the fact that women were highly influential in the church, were also strong contributing factors to its success in the Greco-Roman world.
} 
7. The introduction of a postbaptismal anointing associated with the gift and "seal" of the Holy Spirit;

8. The use of Easter week as time for "mystagogical catechesis" (an explanation of the sacramental "mysteries" the newly initiated had experienced).

Although a similar overall pattern also existed in the West, Western sources display some significant differences. Ambrose of Milan, for example, witnesses to a postbaptismal rite of footwashing (pedilavium) as an integral component of baptism. ${ }^{28}$ Some sources from Rome (e.g., the Letter of John the Deacon to Senarius ${ }^{29}$ ) and North Africa (Augustine ${ }^{30}$ ) indicate the presence of three public scrutinies (including even physical examinations) held on the third, fourth, and fifth Sundays of Lent. And, thanks to an important fifth-century letter from Pope Innocent I to Decentius of Gubbio, ${ }^{31}$ it is clear that at Rome itself the pattern of episcopal hand-laying with prayer and second postbaptismal anointing was understood as an essential aspect and was associated explicitly with the bishop's prerogative in "giving" the Holy Spirit.

The adoption of several of these ceremonies for the preparation and baptism of candidates was, undoubtedly, the result of the church seeking to ensure its sacramental life would continue to have some kind of integrity when, in a changed social and cultural context where Christianity was now favored by the emperor, authentic conversion and properly motivated desire to enter the Christian community could no longer be assumed automatically. Defective motivations for "converting" to Christianity included the desire to marry a Christian, as well as the seeking after political or economic gain in a society having become increasingly "Christianized." And, since it was thought that the forgiveness of sins which baptism conveyed could only be obtained once, with the exception of the one-time postbaptismal "canonical penance," there was a widespread tendency to delay baptism as long as possible in order to be

\footnotetext{
${ }^{28}$ See Edward Yarnold, The Awe-Inspiring Rites of Initiation: The Origins of the R.C.I.A. (Collegeville, MN: The Liturgical Press, 1994), 121-123.

${ }^{29}$ Documents of the Baptismal Liturgy, 154-156. [Editor's note: $3^{\text {rd }}$ ed, 208212.]

${ }^{30}$ Ibid., 103. [Editor's note: $3^{\text {rd }}$ ed., 145-146.]

${ }^{31}$ Ibid., 229-230. [Editor's note: $3^{\text {rd }}$ ed., 205-206.]
} 
more sure of winning ultimate salvation. Even Constantine himself was not baptized until he was on his deathbed.

Because entry into the catechumenate assured one's status as a Christian, the postponement of baptism became a common practice in this period and there were those, who, like Constantine, remained catechumens for life. Indeed, as the experience of Augustine himself demonstrates, ${ }^{32}$ it became common in some places to enroll infants in the catechumenate and then postpone their baptism until later in life, if ever. Similarly, as the rites themselves take on from a Greco-Roman mystery religions context either numerous ritual elements or interpretations of the rites that heightened dramatically the experience of those being initiated, the overall intent was surely to impress upon the catechumens and elect the seriousness of the step they were taking. ${ }^{33}$

It is not, however, only the baptismal candidates who seem to have regularly experienced this process. Egeria, the late-fourth century Spanish pilgrim to Jerusalem near the end of Cyril's episcopate, records in her travel diary that, along with the candidates and their sponsors, members of the faithful also filled the Church of the Holy Sepulchre in Jerusalem for the daily catechetical lectures of the bishop. "At ordinary services when the bishop sits and preaches," she writes, "the faithful utter exclamations, but when they come and hear him explaining the catechesis, their exclamations are far louder ...; and ... they ask questions on each point." Further, during the Easter week of mystagogy, she notes that the applause of the newly baptized and faithful "is so loud that it can be heard outside the church." Because of this, she states that "all the people in these parts are able to follow the Scriptures when they are read in church." ${ }^{34}$

Designed, of course, with adult converts in mind, the overall ritual process of baptism in these several sources was to be short-lived, due, according to John Baldovin, to its success. ${ }^{35}$ In other words, it eventually died out, in part at least, because, apparently, it had worked and, for good or ill, the empire had become "Christian"! The North African controversy

${ }^{32}$ Confessions 1.11 .

${ }^{33}$ Yarnold, The Awe-Inspiring Rites of Initiation, 59-66.

${ }^{34}$ John Wilkinson, Egeria's Travels, rev. ed. (Jerusalem: Ariel Publishing House, 1981), 144-145.

${ }^{35}$ John Baldovin, "Christian Worship to the Eve of the Reformation," in The Making of Jewish and Christian Worship, ed. Paul F. Bradshaw and Lawrence A. Hoffman (Notre Dame, IN: University of Notre Dame Press, 1991), 167. 
between Pelagianism and Augustine over the long-standing practice of infant initiation, and Augustine's theological rationale for infant initiation based on a theology of original sin, however, will lead to its further decline, even if, in the case of Rome, it would still be contained in the various liturgical books. At the same time Augustine's lengthy battle with Donatism, over the Donatist practice of "rebaptizing" Catholics and their insistence on the moral character of the baptizer in assuring the validity of baptism in the aftermath of the Diocletian persecution, will lead also to an orthodox sacramental theology based on the use of proper elements and words with Christ himself underscored as the true sacramental minister. If Augustine himself knew an initiation rite similar to those summarized above, ${ }^{36}$ his own theological emphases, born in the heat of controversy, would set the agenda for what I refer to as a later Western-medieval "sacramental minimalism" focused on "matter" and "form," the quamprimum ("as soon as possible") baptism of infants, and an objective sacramental validity ensured by an ex opere operato understanding.

In spite of the apparent success of this baptismal process in early Christianity, however, we should be careful not to romanticize it today. We have little to corroborate Egeria's perhaps exaggerated description of the apparently large numbers of catechumens and faithful in late-fourth century Jerusalem who gathered to hear Cyril's lectures and who greeted them with thunderous applause. Jerusalem, after all, was a major pilgrimage center, whose liturgical practices may or may not have been typical of churches elsewhere or everywhere. In other words, while we know that such a baptismal process clearly existed in the church of this period, we do not know how many people actually went through such an extended catechumenate in preparation for baptism or what the overall ritual shape of baptism was really like in the various and numerous parish churches themselves. For that matter, even Easter baptism, notes Paul Bradshaw, appears to have been a "custom" that lasted for only about fifty years in some places, and there is enough evidence to suggest that, even if it remained on the books as the theoretical "norm," other occasions besides Easter, such as Epiphany, the feasts of particular local martyrs, and even Christmas remained and continued in some places, even in the West, as baptismal occasions. ${ }^{37}$ Our evidence for this "Golden Age" of baptism,

\footnotetext{
${ }^{36}$ See William Harmless, Augustine and the Catechumenate (Collegeville, MN: Liturgical Press, 1995), 79ff.

${ }^{37}$ See Paul Bradshaw, “'Diem baptismo sollemniorem': Initiation and Easter in Christian Antiquity," in Living Water, Sealing Spirit, 137-147.
} 
then, is pretty much limited to the practice of the large patriarchal and pilgrimage centers and to surviving texts from their illustrious bishops. Hence, we should not automatically assume that everyone everywhere was doing this anymore than we should assume that actual parish liturgical practice today can be read from liturgical manuals, the texts of our current worship books, or from exceptional parishes and university churches.

Nevertheless, as an excellent and proven manner by which the early churches, in a changed social and cultural environment, attempted to form adult converts, in the power of the Holy Spirit, by a highly ritual-sacramentalized, all-encompassing process "in the Word, prayer, worship, Christian community, and service in the world," 38 this process still has much to commend itself for our usefulness today. It is to this, my final point, that I now wish to turn.

\section{The Implications or Usefulness of This Spirituality for the Church Today}

However one may assess the contemporary social and cultural context of the church in the United States and world today, whether "postmodern," "post-Christian," or "post-Christendom," it is abundantly clear that we find ourselves today in a world similar to that of the early churches at the beginning of the Constantinian era, with increasing numbers of unchurched, unbaptized, and uncatechized people in our midst, an abundance of competing spiritualities and self-help manuals, varieties of available Gnostic and new "mystery" religions, what some have called a "crisis in morality," what others have labelled the lack of a formative and common narrative by which the world might be ordered coherently, and in which the quest for some kind of life-shaping, ultimate truth is as near and as obvious as the book rack in local grocery and drug stores. Frank Senn has written of the challenges of our age, saying,

we need to preserve, provide, and protect the forms and content of orthodox Christian worship; we need to be sensitive to the culturally-conditioned needs, quests, and forms of expression of the generations who come to worship; and we need to be alert to, in conversation with, and wary of the "post-modern" world that is emerging ... Contemporary quests for wholeness, community, and transcendence should be welcomed, even as we recognize that quests for these conditions constitute a rejection of the compartmentalization, individualism, and immanentalism of the "modern" worldview. At the same time the faith community

${ }^{38}$ Chicago Statement on Worship and Culture: Baptism and Rites of Life

Passage, par. 2.1., note 6. 
has its own ways of addressing these issues, all of them rooted in its historic liturgical life. Only by exploring these historical liturgical traditions can we reach out to the rising generations with something that at least matches their quests. ${ }^{39}$

The publication of resources like Welcome to Christ provides us Lutherans with a golden opportunity to "reach out to the rising generations with something that at least matches their quests," and, in the process, to renew parish life at all levels in exciting ways with "the heartbeat of the sacraments" at the very center. One of the explicit goals of the InterLutheran Commission on Worship in the publication of the Lutheran Book of Worship, you recall, was "to restore to Holy Baptism the liturgical rank and dignity implied by Lutheran theology," 40 and Welcome to Christ can be a major part of that still-needed and ongoing process of restoration. Indeed, the overall importance of the modern restoration of the adult catechumenate for the faith and life of the contemporary church cannot be overestimated! "What the Roman documents contain," wrote Aidan Kavanagh of the Roman Catholic RCIA several years ago, "are not merely specific changes in liturgical rubrics, but a restored and unified vision of the Church." That's what a baptismal spirituality provides, a vision of the church. Kavanagh continues:

One may turn an altar around and leave reform at that. But one cannot set an adult catechumenate in motion without becoming necessarily involved with renewal in the ways a local church lives its faith from top to bottom. For members of an adult catechumenate must be secured through evangelization; they must be formed to maturity in ecclesial faith through catechesis both prior to baptism and after it; and there must be something to initiate them into that will be correlative to the expectations built up in them throughout their whole initiatory process. This last means a community of lively faith in Jesus Christ dead, risen, and present actually among his People. In this area, when one change occurs, all changes. ${ }^{41}$

In short, because of the need for the active involvement of the entire faith community in this process, all of our modern attempts at restoring the adult catechumenate do not so much offer a new way to do ritual as much as they offer a new way to be and do the church. Indeed, as several of our

\footnotetext{
${ }^{39}$ Frank C. Senn, “'Worship Alive': An Analysis and Critique of 'Alternative Worship Services,"” Worship 69/3 (1995), 224. 8.

${ }^{40}$ Lutheran Book of Worship (Minneapolis: Augsburg Publishing House, 1978),

${ }^{41}$ Aidan Kavanagh, "Christian Initiation in Post-Conciliar Catholicism: A Brief Report," in Living Water, Sealing Spirit, 8-9.
} 
Roman Catholic colleagues, based on their experience with the RCIA, can testify, in those places where the adult catechumenate leading to full Christian initiation in water, chrism, and eucharistic table has been restored, and along with it, the immense variety of lay ministries needed (e.g., catechesists, sponsors, and the role of the entire faith community in general) to lead and assist in such a process of conversion, parishes themselves have experienced a renewal in faith and life. They have recovered of the dignity of their baptism and have a renewed sense of their own identity as church, as the body of Christ on mission in the world. That possibility awaits us as Lutherans as well if we "replunge ourselves" into the great tradition, and if, in the words of George Lindbeck, "rather than present experience being allowed to hold sway over the inherited tradition," we let "the inherited tradition shape and govern present experience." ${ }^{42}$

Even if rooted in the answers of the church in a much older historical context, the modern recovery of this patristic-based baptismal process can not be written off today as mere "Golden Age Romanticism" on the part of modern "high church" armchair liturgists who might like to dress up in ancient costumes and "play church." The increasing numbers of unbaptized and/or "unchurched" adults today would seem, just as it did in the context of the fourth and fifth centuries, to call the church to assist in the evangelization and formation of new Christians with authenticity and integrity. Indeed, if current estimates are correct that there are approximately 100 million unchurched people in the United States alone, the need for an adult catechumenal process of formation should become increasingly obvious to us. The issue is not only liturgy, but it is evangelism and formation in Christ and the church. And the great gift of our classic liturgical tradition is that we don't have to invent a new process for this but can receive it from our ancestors in the faith most gratefully.

There are, however, several pitfalls or concerns to be avoided in a modern recovery of this process, some of which, unfortunately, have been incorporated already into the current version of Welcome to Christ itself. First of all, since this baptismal process is, historically and theologically, about the preparation of unbaptized adults for baptism into Christ and the church, it is most unfortunate that, like its Roman Catholic RCIA counterpart, the texts of Welcome to Christ also provide for the presence in this catechumenal process of those who seek to become "Lutherans"

\footnotetext{
${ }^{42}$ George Lindbeck, cited by Wainwright in Worship with One Accord, 156, emphasis added.
} 
through the rite of Affirmation of Baptism. ${ }^{43}$ It is well known that in Roman Catholic circles today the Easter Vigil, in spite of official directives to the contrary, has become the prime time not only for adult baptism but for the Rite of Reception into Full Communion with the Catholic Church and confirmation for those who seek through this catechumenal process to become Roman Catholics. The Easter Vigil, I fear, is rapidly becoming not a baptismal occasion but the great festival of Christian disunity, a "New Members Night" and/or an "Ecclesial Musical Chairs Night" wherein already baptized members of Christ's one body pass from one particular way of ecclesial living into another. ${ }^{44}$ On this night some are joined to Christ through the paschal sacraments of baptism and Eucharist, but several become Roman Catholics, Lutherans, Episcopalians, and others through a combination of other rites after experiencing a similar process of formation. Let, then, the catechumenate be the catechumenate, let the dignity of baptism be paramount, and let us find another time for the reception of those who used to be called "converts." While the need for extended catechesis might often be similar to those who are unbaptized, the dignity of baptism itself suggests that the two groups and occasions not be mixed. For the same reasons, I would suggest strongly that this process can not become yet another "program" in religious education or a replacement for what we have come to call confirmation ministry, even if some aspects of this formative process might be adapted in some ways.

Second, I am concerned along similar lines that Welcome to Christ, comparatively speaking, is, at times, too narrowly parochial in its overall orientation. To provide unbaptized adults with copies of Luther's Small Catechism and a copy of the congregation's worship book, for example, is one thing and to be expected. To do that publicly in the context of the Sunday liturgy is quite another, and may, indeed, unnecessarily confuse the process of becoming baptized with becoming "Lutheran." 45 There is, of course, no question but that the sacraments of the church do take place within specific and particular local manifestations of the church catholic, which will necessarily involve the doctrinal and other stances of those local communities. And yet, the very transcultural and ecumenical nature of

${ }^{43}$ See Welcome to Christ: Lutheran Rites for the Catechumenate (Minneapolis: Augsburg Fortress, 1997), 14-15.

${ }^{44}$ See Maxwell E. Johnson, "Let's Stop 'Making Converts' at Easter," Catechumenate: A Journal of Christian Initiation 21/5 (September 1999): 10-20.

${ }^{45}$ See Welcome to Christ: Lutheran Rites for the Catechumenate, 21. 
baptism would seem to suggest we exercise great care in our public ritual celebrations here lest our ritual actions convey a message we do not intend.

Third, I am also concerned that, apart from a reference to the possibility of this catechumenal process taking place at other seasons, Welcome to Christ tends to put what I like to call "all of our baptismal eggs into the Easter basket."46 I have no qualms whatsoever about giving a theological priority to Easter in terms of a baptismal theology flowing from Romans 6, a theology that emphasizes not only death, burial, and resurrection but also a process of lifelong conversion, that daily baptismal death and resurrection as we know it from Luther's Small Catechism. But this does not mean, necessarily, that Easter always has a liturgical priority for celebrating baptism. Several other occasions are equally suited, and have been used historically, even for the full process envisioned by Welcome to Christ. At the very least, the feast of the Baptism of our Lord, on the Sunday after the Epiphany, is most suitable for this, and attending to this might help us recover the baptismal meaning of Advent in the life of the church, especially with the frequent appearance of John the Baptist in the Advent Gospel readings each year, and even with the use of Titus 3 in the lectionary for Christmas itself. Here, if death and resurrection is not dominant, new birth in water and the Spirit, baptismal adoption, and being equipped for mission might suggest themselves theologically. The construction even of an Epiphany Vigil with several Old Testament readings could easily be done, and there is historical precedent for this even in the West. With regard to Epiphany as a baptismal occasion, the earlier Canadian version of the Lutheran catechumenate, Living Witnesses: The Adult Catechumenate, is to be commended here for providing a clear Advent to Epiphany adaptation of this process. ${ }^{47}$

Along with Epiphany, of course, Pentecost-the great feast of the Spirit, the very culmination and fruit of Jesus' death and resurrection - is certainly suitable, again, with a traditional vigil often attached or easily constructed, and, for that matter, the feast of All Saints in November could also be chosen. I have no objections to Easter baptism at all, but these other feasts of the church may actually help to remind us of the other equally inviting interpretations of baptism that form part of the rich mosaic

${ }^{46}$ Ibid., 19.

${ }^{47}$ See Gordon Lathrop, Living Witnesses: The Adult Catechumenate, Congregational Prayers to Accompany the Catechumenal Process (Winnipeg: Evangelical Lutheran Church in Canada, 1992). 
of baptismal images in scripture and the classic, early Christian, liturgical tradition. I think we would do well to explore them more fully both theologically and in our pastoral-liturgical practice. Indeed, the words of Tertullian in this context bear repeating: "If there is any difference of solemnity, it makes no difference to the grace." ${ }^{\$ 48}$

Fourth, excitement and enthusiasm about the recovery and restoration of this process can lead to the impression that infant baptism in the life of the church is to be downplayed or undervalued. Again, it is Aidan Kavanagh, who, in 1977, stated "that the days of baptism in infancy and confirmation in adolescence as our norm are numbered."49 But, so far at least, Kavanagh's prediction was wrong. By all accounts infant baptism is here to stay, and it should be here to stay both theologically and pastorally. Yet, this does not mean that infant baptism itself cannot be incorporated somehow into this catechumenal process as well, just as it appears to have been done in the early centuries of the church. I have always been intrigued by the rubrics in the seventh- or eighth-century Gelasian Sacramentary and elsewhere that continue to assume parents are to bring their elect infants to the public Lenten scrutinies, now by this late date shifted to weekdays and increased to seven in number, before Easter baptism. Of this process the great historian of the catechumenate Michel Dujarier writes:

we must stress that there was a kind of 'catechumenate' for infants. It is interesting to note that, even for babies, the celebration of baptism was not limited to one single liturgical ceremony. The practice of seven scrutinies on the weekdays of Lent developed when there were many infants among the candidates. The testimony of Caesar of Arles in the sixth century is irrefutable: addressing himself to mothers bringing their babies to the scrutinies, he urged them not to miss these celebrations. This custom was undoubtedly a vestige of the tradition of baptizing infants at the same time as adults.... This custom also had the great advantage of having the parents of these infants participate in the preparation for baptism. Since the parents 'answered' for their children, it was normal that they make the catechetical and liturgical journey leading to baptism. ${ }^{50}$

${ }^{48}$ Documents of the Baptismal Liturgy, 9. [Editor's note: $3^{\text {rd }}$ ed., 10.]

${ }^{49}$ Aidan Kavanagh, "Christian Initiation in Post-Conciliar Roman Catholicism: A Brief Report," in Living Water, Sealing Spirit, 1.

${ }^{50}$ Michel Dujarier, A History of the Catechumenate (New York: Sadlier, 1979), 133 
The recovery and restoration of the catechumenal process should in no way be interpreted as a preference for adult over infant baptism-far from it. Rather, including infant baptism into this process may even afford us other opportunities for exploring how we might do prebaptismal catechesis with parents more effectively and incorporate even that process somewhat into the public liturgy of the church. To that end Gail Ramshaw has written a delightful essay on adapting the catechumenal process to infant baptism in a manner that goes all the way from conception and birth to the celebration of baptism and first Eucharist. ${ }^{51}$ Indeed, it may well be the selection of suitable baptismal occasions according to the calendar of the liturgical year would provide several opportunities each year for some kind of adaptation of this process for the baptism of infants and the continual "mystagogical" or catechetical formation of their parents in the gift of their own baptisms.

Fifth, and finally, my greatest concern about the recovery and restoration of the classic early Christian baptismal process outlined and detailed in Welcome to Christ has little to do with the process itself and much to do with several other things needing to be accomplished if this process is going to become little more than another "resource" for a few liturgically-minded pastors and parishes. Kavanagh's comment, quoted earlier, that "there must be something to initiate [catechumens] into that will be correlative to the expectations built up in them throughout their whole initiatory process ... [i.e.,] a community of lively faith in Jesus Christ dead, risen, and present actually among his People" must be taken seriously. As this process has been shaped in Welcome to Christ, then, its use necessitates, I believe, that at the very least, our parishes once and for all finally restore Sunday Eucharist to its rightful place at the heart of worship; that the season of Lent be rescued finally from its medieval Passion history, seven-last-words-of-Christ devotional dominance in favor of baptismal preparation and renewal; that not only the Easter Vigil but the entire paschal Triduum become the annual center of parish life; that pastors, mission-developers, and parish education directors be formed so they are able to lead in this process; that not only at the national level but on the synodical and district levels there be trained-and paid-directors of liturgy to assist parishes with this process and in other liturgical manners; and that synod and district bishops and presidents and their staffs themselves be converted to see this liturgical-sacramental process is the

\footnotetext{
${ }^{51}$ See Gail Ramshaw, "Celebrating Baptism in Stages: A Proposal," in Alternative Futures for Worship, vol. 5, Baptism and Confirmation, ed. Mark Searle (Collegeville, MN: Liturgical Press, 1987), 137-156.
} 
synthesis of everything the church is about-its worship, education, evangelism, stewardship, and social ministry - all rolled into one grand spirituality of life in Jesus Christ to the glory of God in the Holy Spirit. Until this happens, I fear our modern adaptations of what the early church called "baptism" will simply be one available "resource" among several others, take it or leave it, from which a selection is made in determining various evangelism and educational curricula.

While serving in a previous parish I had an ongoing argument with a bishop's assistant about what the most important element of parish ministry was. I, of course, said it was worship, while his response was people with strong commitments to the other areas of parish life - evangelism, education, stewardship, or social ministry - might make similar and equally valid claims. Although it is still beyond my comprehension how we can even begin to speak of the other areas of ministry without the foundation of Word and sacrament in their liturgical and life-shaping contexts, the recovery and restoration of the classic pattern of baptism in Welcome to Christ, in spite of several pitfalls and concerns, means we don't have to choose among several options. All of them are included under the umbrella of Word and sacrament themselves.

Finally, let me return to Wainwright's statement, that "without the heartbeat of the sacraments at its center, a church will lack confidence about the gospel message and about its own ability to proclaim that message in evangelism, to live it out in its own internal fellowship, and to embody it in service to the needy." That's what early Christian baptismal spirituality has to teach us still today: the restoration of "the heartbeat of the sacraments" at the center of church life, in order that we might have confidence about the gospel and our ability to proclaim it effectively, to live it out in our corporate, ecclesial lives, and to embody it faithfully in lives of martyria and diakonia in the world. That is, let us embrace this willingly so that in our "postmodern," "post-Christian," or "post-Christendom" context we, like saints before us, may proclaim the very common narrative by which we live and which gives life to the world, and so offer a solid spirituality for those who seek a true life in the Spirit worthy of the term "spirituality." 